\title{
South African Old Testament criticism: Squeezed between an ancient text and contemporary contexts
}

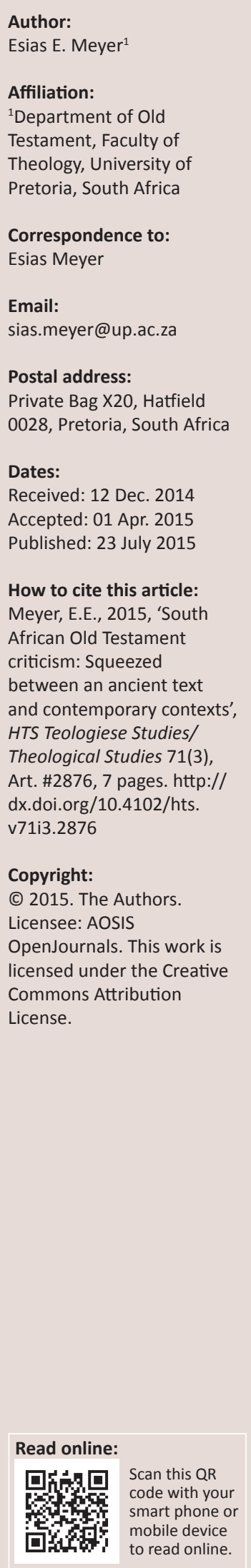

The article focuses on a debate initiated by Masenya and Ramantswana in 2012 about the lack of engagement with contemporary issues by South African Old Testament scholars. The article shows, with reference to the book of Leviticus, that ancient texts grew over time in order to become relevant for later generations. It then asks: if it is possible for Old Testament scholars to construct ancient examples of writers engaging with contemporary issues, why these same scholars are reluctant to make these texts relevant for today? The article then engages with the work of Farisani and describes strong points and weaknesses in the way in which he uses biblical texts to engage with contemporary debates before returning to the central question.

\section{Introduction}

In 2012 Madipoane Masenya and Hulisani Ramantswana wrote an article in which they evaluated all articles published in Old Testament Essays between 1994 and 2010 in the light of the following question: 'Does SA OT scholarship reflect a paradigm shift from being mostly focused on the biblical text and its original context to reflecting more on contemporary issues?' (Masenya \& Ramantswana 2012:599).

They took as their starting point a book by Jurie le Roux (1993), in which Le Roux allegedly argued that SA OT scholarship was usually 'focused on the ancient text rather than contemporary issues', to formulate this question at the start of their article (Masenya \& Ramantswana 2012:599). ${ }^{1}$ They contrasted Le Roux's description of Old Testament scholarship with an article by Ferdinand Deist (1992) in which he 'called upon his predominantly white colleagues to seek to give birth to "an indigenous South African tradition of Old Testament scholarship"' (Masenya \& Ramantswana 2012:604). Then they ask whether South African Old Testament scholarship responded to the challenge posed by Deist in 1992, or continued in their old ways as described by Le Roux. In their evaluation of South African Old Testament scholarship between 1994 and 2010 they came to the conclusion that 'the historical critical trajectory appears to have captured the hearts of SA OT scholars' (Masenya \& Ramantswana 2012:634), which for them means that SA OT scholars are more Eurocentric than 'African'.

I do think that the challenge posed by Masenya and Ramantswana is something which should be taken extremely seriously and I wonder why the challenge posed by Deist in 1992 was not taken seriously by other scholars. The strange thing for me about his challenge is why he himself struggled to rise to it. The monograph he wrote before his death focused only on the ancient world of the Bible from a cultural-anthropological perspective and did not engage with contemporary issues (Deist 2000). This was not entirely his own fault since he died in 1997 and therefore did not have much time. And one should also keep in mind that the challenge posed by Deist was at a symposium at the Faculty of Theology at Stellenbosch in 1991. At that stage Deist was still working at the University of South Africa (UNISA), at a Faculty of Theology as well, but from 1992 he himself moved back to Stellenbosch to teach Ancient Near Eastern Studies in the Arts Faculty of that university. His task was not to teach theology anymore, but rather the Ancient Near East. Still, he did write quite a few more popular books in Afrikaans in which he did engage with contemporary issues. Among these books count quite a few written against apartheid. ${ }^{2}$

In short, I think that Masenya and Ramantswana have a point and they pose a valid challenge, as did Ferdinand Deist 23 years ago, and my question is: Why are most Old Testament critics

\footnotetext{
1.I do not agree with Masenya and Ramantswana on this summary of Le Roux's book. The point of the book was actually that even if South African OT scholarship was characterised by both historical-critical approaches and text-immanent approaches, the former mostly played second fiddle the latter. Le Roux (19.35is accepted or digested by the South African theologinal more interested in hint the text' an tended to present a-historical readine should not be there, as it credits past South African OT scholarship with a historical consciousness which was, according to Le Roux, not always present.

2.One of the best examples is the book 'Sorry, Sam' which tells the story of the friendship between Ferdinand Deist and Prof. Sam
} Abrahams during the apartheid years (Deist 1993). 
in South Africa reluctant to be 'relevant', or as Masenya and Ramantswana put it, do most of us fail 'to reflect on more contemporary issues?' Unfortunately, Masenya and Ramantswana are not all that clear on how exactly they think Old Testament scholars should engage with contemporary issues, not to mention the fact that they do not identify specific contemporary issues. At one stage Masenya and Ramantswana (2012:604) argue that it is wrong to take "'refuge" in approaches that leave the status quo of South African inequalities undisturbed' and then add that there is nothing wrong with using 'exegetical-hermeneutical methodologies,'3 as long as the methodologies 'enable exegetes to interact constructively with the real lives of the flesh-and-blood readers of biblical texts, particularly those located in our contexts.' Yet how are biblical critics to interact with 'flesh-and-blood readers of biblical texts'? The articles are positive about including the one by Richards (1994) who deals with the challenges faced by a black male in a guild dominated by white males. They also refer to articles by Jonker (1997) on the gap between ordinary and professional exegetes, by West $(1997,1998,2006)$ on his approach of 'reading with' lay readers, as well as to Masenya's (1997, 1998, 2002) own Bosadi readings and Holter's (1998) overviews of African Old Testament scholarship, to name a few. On the negative side they seem to disagree strongly with Lombaard (2006) and understand his work as a 'defence of the status quo' (Masenya \& Ramantswana 2012:622). One problem with their article is that they themselves do not spell out how the guild of Old Testament scholars should make things better, or how to change the status quo.

Hence, this article will attempt to engage with the challenge they pose to Old Testament criticism in South Africa. I will do this in three phases. In what follows, I will first venture into a historical-critical or diachronic debate with regards to Leviticus. I will try to show that it is possible to regard the second half of Leviticus as an ancient attempt to engage with what were then 'contemporary issues'. Secondly, I will engage with the work of a fellow Old Testament scholar who has tried to be 'relevant' and engage with contemporary issues, a scholar whose work made the list of the African Qohelets on more than one occasion. ${ }^{4}$ Finally, I will conclude with a

3.According to Masenya and Ramantswana (2012:604), this concept is taken from Lombaard (2006:145-155), which might seem a bit puzzling since Lombaard never refers to 'exegetical-hermeneutical methodologies'. He actually distinguishes between 'exegetical-theological' and 'hermeneutical-theological' studies. The former is used to describe more traditional methodologies such as historical criticism (Lombaard 2006:144). The latter refers to 'feminist, liberation - with as criticism (Lombaard 2006:144). The latter refers to 'feminist, liberation - with as
locally influential branches Black and African - and ecological theologies' (Lombaard locally influential branches Black and African - and ecological theologies' (Lombaard
$2006: 145)$. It thus seems that Masenya and Ramantswana have a bone to pick with 'exegetical-hermeneutical methodologies' and, if one looks at the articles with 'exegetical-hermeneutical methodologies' and, if one looks at the articles
which make their list of approved contributions, they are all for 'hermeneuticalwhich make their list of approved contributions, they are all for 'hermeneutical-
theological' studies. It is strange that they combine these terms together into one rather confusing conceptual concoction.

4.See Farisani (2002), Farisani and Farisani (2004) and Farisani (2005). A valid question would be why I am not using the work of either Ramantswana or Masenya. With regard to Ramantswana the answer is fairly simple. He is a young scholar and much of his work appeared after, or in the same year, as the discussed article by him and Masenya. None of his own work is thus mentioned. Ramantswana (2012, 2013a, 2013b, 2013c, 2014) has published a lot on the creation narratives. Very few of these articles would have made the list of the 'African Oohelets', except for 2013 these articles would have made the list of the 'African Qohelets', except for $2013 a$, where Ramantswana (amongst other things) engages with African cosmology, but this article was not published in OTE. Most of these articles use traditional 'Western methodologies. Eleven of Masenya's own articles are listed in the article by her Touth African theological journals. Her work is that amount of articles in other South African theological journals. Her work is simply too vast to do justice to in an article like this. very short and rather open-ended discussion on the stated problem.

\section{From cult to community}

The term 'Holiness Code' was coined in 1877 by Klostermann (1877:385). ${ }^{5}$ The reason for the name 'Holiness Code' was clear from the start, since we find the command to be holy often enough in the collection ( $\operatorname{Lv} 19: 2,20: 26$ and 21:8, but also 11:44). For many years after Klostermann, the majority view was that this was a much older code which at some stage was incorporated into the Priestly source/composition (P). ${ }^{6}$ For Wellhausen, for instance, the moral issues addressed by Leviticus 17-26 reflected something of an older religion still closely connected to agriculture (Trevaskis 2011:4). In terms of dating it was thus for some time regarded as something that predates the rest of the Priestly text $(\mathrm{P})$ and which could thus have been pre-exilic.

In the second half of the 20th century things started to change. German scholars such as Elliger (1966) and Cholewinski (1976) presented convincing arguments that the Holiness Code already knew of texts such as $\mathrm{P}^{7}$ and Deuteronomy and that it indeed attempted to be some kind of supplement to these two texts. Other European scholars such as Otto (1999), Grünwaldt (1999), Nihan (2007), and now Hieke (2014a, 2014b) have followed suit and it is fairly safe to say that (in Europe at least) the ascending voice is the one that regards Leviticus 17-26 as a post-priestly composition which is to be dated in the Second Temple or Persian Period. Thus, Leviticus 17-26 is later than P and Deuteronomy, and both $\mathrm{P}$ and $\mathrm{H}$ came into being in the post-exilic period. ${ }^{8}$

If one follows the argument about the Persian dating of $\mathrm{H}$, the authors are usually understood as priests themselves, but already from a subsequent generation to the one who produced P (see Hieke 2014a:72). Priestly writings have not been regarded as particularly 'moral', but were mostly portrayed as if 'priests were pre-occupied with the technicalities of ritual and had little or no interest in matters pertaining to ethics or morality' (Balentine 1999:167). This caricature of $\mathrm{P}$ has been taken for granted since Wellhausen established his documentary hypothesis. ${ }^{9}$ Yet, the Holiness Code has always (at least since the days of Wellhausen) been

5.This work was first published in 1877 in Zeitschrift für die gesammte lutherische Theologie und Kirche. The journal is not published any more. 6.See also Wellhausen's comment as quoted by Jüngling (1999:29) and Otto
(1999:132). Both quote from an article published by Wellhausen in 1877, which (1999:132). Both quote from an article published by Wellhausen in 1877, which
is the same year in which Klostermann coined 'Heiligkeitsgesetz'. Wellhausen identified elements in Leviticus 17-26 whereby 'sie sich dem Deuteronomium und identified elements in
dem Ezechiel nähern'.

7.For my purposes the distinction between $\mathrm{Pg}^{\mathrm{g}}$ and $\mathrm{P}^{\mathrm{s}}$ is not that important, since both are older than the Holiness Code. In this regard I follow Nihan (2007:546), who does not distinguish between the two.

8.There are also some Jewish scholars in the Kaufmann school who would agree with the fact that Leviticus 17-26 postdates P, but who would like to date both much earlier. A good example of this line of thought is Knohl (1995), who dates Leviticus 17-26 in the time of Ahaz and Hezekiah (c. 743-701 BCE). Another important $17-26$ in the Milgrom (1991, 2000 and 2001). But few European scholars have taken example is Milgrom (1991, 2000 and 2001). But few European scholars have taken 17-26, I would prefer to follow the European consensus (see Meyer 2010).

9.According to Ska (2006:111), "Wellhausen was translating the Lutheran "creed" regarding the Law and the Gospel into historical categories'. This explains why Wellhausen was so negative about P, since it became the Lutheran 'Law'. 
regarded as something different from the first 16 chapters of Leviticus, and a lot has been written about these differences. Two important things changed between Leviticus 1-16 and $17-26$

The first is the conceptual change in which the meaning of the term 'holiness' was altered. ${ }^{10}$ Schwartz (2000:54) clearly shows how initially holiness was only used for 'the priests, the tabernacle and its appurtenances, holy days, offerings and the Tetragrammaton' in earlier priestly thought. Yet in $\mathrm{H}$ 'it is extended to Israel as a whole, as if to say: all of humanity too is divided into the holy (Israel) and the common (everyone else).' This does not mean that the common disappeared, but it is more a case of the sphere of the holy being enlarged to include Israel, while still not including absolutely 'everyone else.' Hieke (2014b:613) in this regard refers to Artus (2013:172), who describes this widening of the applicability of the concept holiness as a 'Demokratisierung' of holiness. Despite the fact that both Artus and Hieke acknowledge that the term is anachronistic, it is still a fairly useful description, since it says something of the fact that, with regard to people, $\mathrm{P}$ uses holiness only for priests, whereas $\mathrm{H}$ includes all of Israel.

Thus, secondly the content of some of the laws in Leviticus 17-26 has often been described as more 'ethical'. Both Milgrom (2000:1400-1404) and Knohl (1995:175-180) present similar views that 'whereas $\mathrm{P}$ is focused on the cult itself and the rituals aimed at maintaining the cult, $\mathrm{H}$ broadens its horizons to include what we might call "ethics"' (Meyer 2013:1). Bibb (2009:152) puts it similarly when he says: 'The central movement [ from $P$ to $H$ ] ... is the shift from a narrow cultic focus to the larger communal setting.' Hieke (2014b:612) furthermore talks of 'Fragen des zwischenmenschlichen Verhalten' [questions about inter-human relations] addressed in Leviticus 17-26, but were mostly absent in chapters 1-16. Important laws include chapters 18 and 20 about sexual ethics, chapter 19 which refers to the Decalogue, protecting the vulnerable (vv. 13-15), ${ }^{11}$ the strangers etc., or the Jubilee in chapter 25 .

A major issue in the interpretation of the book of Leviticus is thus to relate the cultic focus of Leviticus 1-16 with the more ethical focus of Leviticus 17-26, especially in the light of the historical argument that the latter developed out of the former.

The answer to this question is usually that this happened as a result of some kind of inner-biblical discussion. For Knohl (1995:212-215) the broader focus of $\mathrm{H}$ is the result of a response to critique by classical prophets such as Amos, Micah and Isaiah against the narrow cultic focus of P. This argument is part of his broader argument that both $\mathrm{P}$ and $\mathrm{H}$ are

10.The term appears in Leviticus as either verb (קד.............................................. or noune See Meyer (2013:3) for the complete list. With regard to the Holiness Code, most of the important verses in chapters 19-21 make use of the adjective (e.g. 19:2, 20:7, 26, 21:6-8).

11.These laws remind us of the Prophets. See, for instance, the examples mentioned by Milgrom (2000:1626), namely Isaiah 1:17, 23; 3:14-15; 10:2; Jeremiah 5:28; Ezekiel 16:49; 18:17; 22:7, 29; Amos 8:4; Malachi 3:5. Still, Milgrom is adamant that 'what is sometimes forgotten, however, is that concern for the exploited is that ' what is sometimes forgotten, however, is pre-exilic, and it is thus not all that convincing. For somebody such as Otto (1999), the ethical content in $\mathrm{H}$ is also the result of inner-biblical exegesis, which is a process whereby the authors of the Holiness Code were reinterpreting texts from the Decalogue, the Deuteronomic Code and the Covenant Code. The views of scholars such as Nihan (2007:545-559) and Hieke (2014b:612-614) would also be closer to Otto's than to Knohl's, and most European scholars would look for a historical context sometime in the Persian Period.

One could thus say that $\mathrm{H}$ was an attempt by its priestly authors to reinterpret and contextualize the priestly theology they inherited from earlier generations of priests (i.e. P). In the process of reinterpreting their earlier traditions they also engaged with the three other legal codes in the Pentateuch, namely the Decalogue, the Covenant Code and the Deuteronomic Code. They managed to maintain the cultic interests of their Priestly predecessors, but at the same time added insights on how this Priestly world view translates into everyday life, probably addressing issues which were relevant for the communities of Persian-Period Yehud, who were presumably the first addressees of these texts.

One question which is not always explicitly stated when we construct the development of texts over time, what we would call 'diachronic' methods, is why did the texts grow? What impetus was there in a particular historical context for priests or scribes to take a text and to add to it, or to take different texts and combine them into something new? Why did we have Fortschreibung? One answer would be that in new historical contexts texts needed to be made relevant again. Texts became outdated and needed to be updated.

What I have tried to show was that $\mathrm{H}$ might have been an ancient effort to reflect on 'contemporary issues' and this leads to the following question. If the historical-critical tools at our disposal help us to describe how the authors of $\mathrm{H}$ used older texts to engage with their contemporary issues, or even helps us to construct a historical context in which the changes in the second half of Leviticus make sense, why are we reluctant to do something similar in our contemporary context? Why do we not attempt to make texts relevant?

In an attempt to provide some kind of an answer to this question, I will engage with the work of Elulwani Farisani, an Old Testament scholar who does not shy away from engaging with contemporary issues. I present his work as an example of what some think we should be doing as Old Testament critics. Farisani's work makes the list of the African Qohelets (see footnote 5).

\section{An 'ideologically aware' approach to the Bible}

In 2010 a special issue of the Stellenbosch Journal Scriptura was published about the current state of Black Theology. I will start with the article by Elulwani Farisani in this journal and then work my way back in time with reference to a 
handful of articles published by him in the past decade. The question I kept on asking myself was: 'How is the kind of Black biblical hermeneutics presented by Farisani different from what other biblical critics are doing with Old Testament texts?' Is this thus what we should be doing according to Masenya and Ramantswana? The title of this 2010 article is ‘Black biblical hermeneutics and ideologically aware reading of texts.'

Farisani (2010:507) starts this article by first summing up what he understands by 'ideology' by referring to a definition of Nielsen which has a profound Marxist ring to it, namely a set of ideas which serves a certain class by 'putting itself forward as answering the interests of the whole of society.' In the rest of the article he sets out to provide an overview of the development of Black biblical hermeneutics and the role it played in the struggle against oppression, the critique of Black Theology by Mosala (1989), and his own critique of reconstruction theology and its 'ideologically unaware' reading of biblical texts. Farisani then concludes with what he thinks the role of Black Theology should be in postapartheid South Africa. In short he argues that a 'sociological analysis of biblical texts' is required and should be the main tool in the hands of Black Theology to 'unearth the ideologies imbedded in biblical texts'. What does he mean by 'sociological analysis?' We'll return to the question later.

Farisani (2010:509-512) follows in the footsteps of Mosala (1989) who has presented an extensive critique of Black Theologians such as Alan Boesak, for instance, for his lack of 'ideological awareness' when using the Old Testament. ${ }^{12}$ Mosala used the same critique against the 'historical-critical method' and 'the social scientific method'. ${ }^{13}$ Mosala's main argument was that these methods were not really interested in identifying the 'ideology of a text', and once again ideology is defined as something serving the class interests of a group. Farisani clearly acknowledges his indebtedness to Mosala; and one of the important contributions made by Farisani (2010:512-513) to the South African debate was his critique offered against scholars such as Jesse Mugambi (1995) and Charles Villa-Vicencio (1992) and their theology of reconstruction. In a sense Farisani did to them what Mosala did to an earlier generation of Black theologians.

According to Farisani (2010:513-514), Mugambi argued that, after the abolition of apartheid, the exodus metaphor had run its course and that something new was needed. ${ }^{14}$ Mugambi proposed a theology of reconstruction in which the book of Nehemiah could play an important role. ${ }^{15}$ Nehemiah

12.See, for instance, the chapter entitled 'The use of the Bible in Black Theology' (Mosala 1989:13-42). The name of Alan Boesak features a lot in this chapter.

13.See especially Mosala (1989:43-62).

14.A much more extensive critique of Villa-Vicencio and Mugambi is found in Farisani (2002)

15.Mugambi's (1995:166) discussion of the book of Nehemiah covers hardly a whole paragraph. He thinks that the book of Nehemiah might become the 'central biblical text for African Christian theology in the 21st century'. Mugambi (1995:166) text for African Christian theology in the 21st century'. Mugambi (1995:166) continues to warn that the book 'should be read critically, taking into consideration
all the hermeneutical, exegetical, theological and ethical limitations associated all the hermeneutical, exegetical, theological and ethical limitations associated
with the reconstruction project of Nehemiah'. Mugambi does not name these limitations, though, and Farisani does well to point them out. becomes the new Moses, if you will, who must lead the nation not out of Egypt, but towards rebuilding its society after the destruction of the exile, or in the case of Africa, after the destruction of colonialism and apartheid. The problem for Farisani is that Mugambi and Villa-Vicencio ${ }^{16}$ did not read these texts carefully. They did not grasp the power struggles between the people of the golah and the am haaretz and, by doing that, they actually participated in the silencing of the am haaretz. They bought into the ideology or political agenda of the returning elite and they used them as a model to reconstruct post-apartheid South Africa. Farisani (2010:514) concludes: 'Rather, he (Mugambi) includes in his post-exilic metaphors different texts from different sociopolitical contexts without doing a sociological analysis of any of them' ${ }^{17}$

Once again one wonders what exactly is meant by ‘sociological analysis' and how this is different from the so-called 'social scientific method' deemed 'ideologically unaware' by Mosala (1989:65) earlier. Farisani (2010:515) then attempts to answer precisely this question. For him, a 'sociological analysis' of a text has two facets to it. Firstly 'it warns against an uncritical reading of a text', which I suppose in itself can mean many things, since few would argue that historical-critical methods were uncritical readings of texts. But for Farisani it is about a specific kind of criticism and especially the fact that texts tend to marginalise and disempower certain people that texts have political agendas from an ancient world. When one is not conscious of this fact one participates in the silencing of ancient marginalised people. A 'rigorous sociological analysis' then attempts to 'de-ideologise' these texts. I am not sure what 'de-ideologise' means, but I would venture it has something to do with discovering what the political agenda might have been behind a particular text, in a specific 'sociohistorical context'.

Secondly, such a sociological reading of the text attempts to read 'against the grain', but unfortunately Farisani (2010:65) is not that clear on exactly what this 'against the grain' reading is supposed to entail, although these concepts have been used by many engaged or contextual theologians. ${ }^{18}$

The question I initially asked is how this kind of reading is different from what historical critics have been doing with Old Testament texts. Historical critics have often engaged with socio-historical contexts. They might not have always used precisely these terms, but it was always about discovering historical contexts in which texts would make more sense. One thing which is clearly different between Farisani and historical critics is the fact that he is not reluctant to apply his interpretations of biblical texts to modern day contexts.

16.Villa-Vicencio (1992:28-29) only briefly mentions Ezra and Nehemiah and actually makes much more of other post-exilic texts such as Deutero-Isaiah. With regard to Ezra and Nehemiah he acknowledges that 'ideological conflicts' are inherent to to Ezra and Nehemiah he acknowledges that 'ideological conflicts' are inherent to these texts (Villa-Vicencio 1992:28). Farisani (2002:632-633) acknowledges this,

17.Similarly, but with regard to Villa-Vicencio, Farisani (2002:634) earlier said that 'he does not go on to read the text carefully in order to isolate ideological agendas does not go on to read the text
which are prevalent in the text'.

18.See also Farisani (2003:44-48) 
This is very clear in one of Farisani's (2005) ${ }^{19}$ earlier articles, where he also sets out to apply certain texts from the OT - and specifically from 1 Kings 21:1-29, the story of Naboth and his vineyard - to a contemporary context. In this article Farisani (2005:47-53) sketches the historical context of the rule of Omri. Farisani describes the introduction of Baal worship by Ahab, the son of Omri, and the corrupt socio-economic practices of the Omrides in general. All of this sets the scene for the rebellion by Jehu and, before that, the confrontation between Elijah and Ahab about Naboth's death (Farisani 2005:55-56). This confrontation is then compared with something which happened between Thabo Mbeki (then president) and Archbishop Tutu in November 2004 at the Nelson Mandela Foundation Lecture. Tutu was very critical of government shortcomings and Mbeki responded by calling Tutu a liar (Farisani 2005:56-58).

Farisani (2005:58-59) compares this confrontation between Tutu and Mbeki with the one between Ahab and Elijah, arguing that Mbeki was wrong and Tutu right. He points to contradictions in Mbeki's response who, on the one hand, asks for an open debate, but then goes on to attack Tutu personally. In both cases it is a confrontation between powerful figures and in both cases the political figure (Ahab/ Mbeki) accuses the other of being a liar. Yet, in both cases the prophet (Elijah/Tutu) has genuine socio-economic concerns which probably bother many ordinary people. This is a classic case in which texts in the OT are compared with modernday events and where it is argued that they are the same; yet historical critics have usually shied away from doing this, whereas in Black biblical hermeneutics these comparisons are quickly made.

I do find one thing strange about this article, especially when compared with Farisani's work on Ezra-Nehemiah, where he clearly sets out to 'de-ideologize' those books. He has written a lot about the power struggle between the golah and the am haaretz, identifying political agendas behind these texts, which we as critics should expose. ${ }^{20}$ I just wonder why the same degree of criticism is not applied to the text of 1 Kings $21 .{ }^{21}$ Why do we not hear anything about the political agenda of the authors of 1 Kings $21 ?^{22}$ It is no secret that the authors of these narratives were mostly pro-Judah and that, whoever the authors were, they clearly liked Southern kings most, especially reformers such as Hezekiah and Josiah (Halloway 1992:78-82). I wonder whether we could really trust the authors of this text to provide us with a fair picture of the rule of the Omrides, or for that matter of any Northern king. 1 Kings 21 also shares a further 'ideology' with Ezra and Nehemiah, and that is the perceived threat of the foreign

19.See also Farisani and Farisani (2004).

20.See Farisani $(2002,2003,2004,2006)$.

21.In all fairness to Farisani, I draw from material published quite some time before 2005. These opinions where thus already part of the bigger debate when Farisani wrote his article.

22.I am not really interested here in whether the text was written by a Deuteronomist as Martin Noth argued a long time ago. The consensus about a Deuteronomistic history does not really exist anymore. See the recent overview by Thomas Röme (2013) on the state of the debate. wife, in Jezebel. Rofé (1988:101-102) has also argued that the role played by Jezebel in the story was added at a later time in which 'foreign women in general are stigmatized', an interpretation supported by Carroll (1991:120-121). For Rofé (1988:102) the 'historical setting is the fight of Ezra and Nehemiah against intermarriage.' Carroll (1991:122) later agrees and thinks that ' 1 Kings 21 may represent more a polemic against foreign wives than a straightforward story about land deals.' Farisani apparently rejects this ideology in Ezra and Nehemiah, ${ }^{23}$ but accepts it in 1 Kings 21.

There are other problems with the text as well, including the discrepancies between 1 Kings 21 and 2 Kings 9:21-26 about the place and time of the incident (Walsh 1992:978). ${ }^{24}$ Some time before the article by Farisani was published White (1994:68-69) had already engaged with these historical discrepancies and, after comparing 1 Kings 21 with the David and Bathsheba story in 2 Samuel 11-12 and showing that the two stories are related, argued that the vineyard story 'is a retelling of Ahab's crime along the lines of the David and Bathsheba story.' For White (1994:69), 2 Kings 9:25b-26a is actually the original story. Among other things, this questions the 'historicity of Elijah's involvement in the affair'. Eventually White (1994:76) concludes that the story in 1 Kings 21 was the creation of one of the scribes of Jehu who wanted to justify and legitimise his cruel coup after the event. White thus sees a different historical setting from that of Carroll and Rofé, but in both cases these historical critics attempt to identify political agendas behind the text, possible agendas which are ignored by Farisani.

Farisani never mentions the arguments by White, Carroll or Rofé, and one wonders why the same dose of 'deideologizing', the same level of 'sociological study' is not applied to this story about an evil Northern king. Why does Farisani dismiss the agenda of the books of Ezra and Nehemiah, but embrace the agenda of the authors of this story, who clearly had an anti-Omride political agenda, not to mention a similar view to Ezra and Nehemiah about foreign wives? Should de-ideologizing not be practised more even-handedly? In short, Farisani's reading of 1 Kings 21 is 'ideologically biased', if I can use his own words.

I do have a lot of respect for Farisani's work; he is very thorough in his reading of (most) texts and hermeneutically he makes a very important point. He warns us to read carefully and not to let ourselves be duped by the ideologies of ancient texts. At times he reminds me a lot of the late Robert Carroll and his kind of Ideologiekritik, ${ }^{25}$ but Farisani is not as consistent as Carroll was. Most of the time Farisani reads like a historical critic. He uses the traditional tools of historical-criticism with great skill, and the only difference between him and more

23.See Farisani (2003:47-48), who mentions that certain texts in Ezra-Nehemiah describe the forceful divorce of women from their husbands whose cries are silenced by the authors. These texts are, of course, Ezra 9 and 10 and Nehemiah 13.

24.Or internal tensions within the 1 Kings 21 narrative itself, as shown by Rofé (1988:94-95)

25.See, for instance, Carroll $(1994,1995)$ 
traditional historical-criticism is the fact that he does not shy away from applying ancient texts with current contexts, or in the parlance of Masenya and Ramantswana, to 'engage with contemporary issues', and this is where things become problematic. The main problem is that when a text such as 1 Kings 21 fits our current political agenda, then Farisani conveniently forgets his ideological approach to texts and buys into the political agenda of the ancient text. Where does this bring us in the broader discussion?

\section{Conclusion}

I started this article by referring to the challenge posed by Deist in 1991, brought to our attention by Masenya and Ramantswana, that as Old Testament critics we should engage more with contemporary issues. Then I offered a summary of what is going on in Leviticus studies at this stage when historical critics - or more specifically, redaction critics describe the Holiness Code as an ancient effort by priestly authors to engage with contemporary issues; 'contemporary' here meaning issues in Persian-Period Yehud. These priestly authors broadened the focus on cult in the first half of the book to community in the second half. I did this to point out that, although we can use the historical-critical tools at our disposal to construct an ancient attempt to become more relevant or contemporary, we at the same time remain reluctant to enter contemporary debates. I then engaged with the work of Farisani, and apart from my appreciation for his ideological-critical approach it seems that he is very willing to forgo that approach when texts fit snugly into modernday political scenarios. And the question remains: Why do I find myself as a biblical critic reluctant to engage with contemporary issues?

One reason has to do with the inconsistencies in many of the attempts to do this, such as one finds in the work of Farisani. Although African biblical scholarship prides itself on interrogating both the text and the African context as Gerald West (2008:55) has often shown, it seems that texts are sometimes not interrogated deeply enough, especially when they seem to fit today's issues so nicely. Ahab effortlessly turns into Mbeki, and Elijah into Tutu, and although we would probably all agree that in that scenario Tutu was right and indeed acting like a true prophet of God, I am not sure why we need an ancient tale to show us that, especially if that ancient tale also had its own political agenda. This is a classical case of anachronism.

Another reason has to do with our training, or mine at least. We have the tools of historical-criticism and nowadays literary criticism as well, but we are not trained in the social sciences and our tools for engaging with contemporary issues are rather blunt. Should we - and by 'we' I mean all those socalled white, European and irrelevant scholars who were in Ramantswana and Masenya's sights when they wrote their article - therefore engage with contemporary issues? I think we should, but I am not sure how, since it seems that many attempts to do that put so much focus on contemporary contexts that they neglect the import of the ancient texts. Or they squeeze the ancient text until it says what we want it to say. ${ }^{26}$

As soon as I say that I sound like one of those historical critics often described by West who stamps his (it usually is a he) foot and says we should focus only on what a text meant and not what it means. I do not want to sound like that, since I know that my construction of ancient history, even my construction of how $\mathrm{H}$ developed out of $\mathrm{P}$, is highly influenced by my own context and that, as West (2008:58) says, 'history is constructed rather than found'. Many historical critics in the past also squeezed texts until they became what these critics wanted them to be, and if African biblical hermeneutics works from the presupposition that we cannot be objective, then I am indeed one, but I am still more comfortable as a biblical critic constructing ancient histories than engaging with contemporary issues. I therefore do not really know why I am reluctant to engage with contemporary issues, but I do think that his debate needs to continue and perhaps African biblical exegetes can help me to discover the answer to this question.

Yet I think that one could take the Holiness Code, such as chapter 19 for instance, and ask about the ethical values or ethos that lies behind these texts. One could take the treatment of the strangers in the Holiness Code and the amount of space they are given as an example of how we could treat strangers in our society. But we should also be warned (as Farisani often warns us) that these post-priestly texts are not necessarily innocent. They also have their political agendas, which were partly about legitimising the power of priests and partly also about creating boundaries around the postexilic community to protect Jewish identity in the Persian period. This act of drawing boundaries is particularly clear in the parenetic frame of the Holiness Code, especially at the end of chapter 20.

Attempts like the one by Hieke (2014b:710-711) to redefine holiness as something which is not only about separation, but also about Israel representing YHWH before the world, are not convincing though. This idea is simply absent from the text and goes against texts such as Leviticus 20:24-26. Holiness still implies separateness, but what is worth noting, as Hieke (2014b:711) indeed does, is that despite the fact that the objective was (in my view) separation and boundary drawing, the authors still envisioned doing this by means of 'ethics' or simply by living differently. These things should be explored by us as South African Old Testament critics.

\section{Acknowledgements Competing interests}

The author declares that he has no financial or personal relationships which may have inappropriately influenced him in writing this article.

26.1 have similar reservations about the use of texts in the debate on ecology. See Meyer (2011). 


\section{References}

Artus, O., 2013, 'Die Pentateuch-Gesetze', in T. Römer, J.-D. Macchi \& C. Nihan (eds.), Einleitung in das Alte Testament. Die Bücher der Hebräischen Bibel und die alttestamentlichen Schriften der katholischen, protestantischen und orthodoxen Kirchen, pp. 165-176, Theologischer Verlag Zürich, Zürich.

Balentine, S.E., 1999, The Torah's vision of worship, Fortress Press, Minneapolis, MN (Overtures to Biblical Theology).

Bibb, B.D., 2009, Ritual words and narrative worlds in the book of Leviticus, T \& T Clark, London. (Library of Hebrew Bible/Old Testament Studies 480).

Carroll, R.P., 1991, 'Textual strategies and ideology in the Second Temple Period', in P.R. Davies, (ed.), Second Temple Studies. 1. Persian Period, pp. 108-124, JSOT Press, Sheffield. (JSOTS 117).

Carroll, R.P., 1994, 'On representation in the Bible: An Ideologiekritik approach', Journal of Northwest Semitic Languages 20(2), 1-15.

Carroll, R.P., 1995, 'An infinity of traces: On making an inventory of our ideological holdings. An introduction to Ideologiekritik in Biblical study', Journal of Northwest Semitic Languages 21(2), 25-44.

Cholewinski, A., 1976, Heiligkeitsgesetz und Deuteronomium, Biblical Institute Press, Rome. (Analecta Biblica 66).

Deist, F.E., 1992, 'South African Old Testament studies and the future', Old Testament Essays 5, 311-331.

Deist, F.E., 1993, Sorry, Sam, J.L. van Schaik, Hatfield.

Deist, F.E., 2000, The material culture of the Bible: An introduction, Sheffield Academic Press, Sheffield. (The Biblical Seminar 70).

Elliger, K., 1966, Leviticus. Mohr, Tübingen. (HAT 4).

Farisani, E., 2002, 'The ideologically biased use of Ezra-Nehemiah in a quest for an African theology of reconstruction', Old Testament Essays 15(3), 628-646.

Farisani, E., 2003, 'The use of Ezra-Nehemiah in a quest for an African theology of reconstruction', Journal of Theology for Southern Africa 116, 27-50.

Farisani, E., 2004, 'A sociological analysis of Israelites in Babylonian exile', Old Testament Essays 17(3), 380-388.

Farisani, E., 2005, 'A sociological reading of the confrontation between Ahab and Elijah in 1 Kings 21:1-29', Old Testament Essays 18(1), 47-60.

Farisani, E., 2006, 'The third return of the Babylonian exiles to Palestine', Old Testament Essays 19(3), 1162-1177.

Farisani, E., 2010, 'Black biblical hermeneutics and ideologically aware reading of texts', Scriptura 105, 507-518. http://dx.doi.org/10.7833/105-0-169

Farisani, E. \& Farisani, D., 2004, 'The abuse of the administration of justice in 1 Kings 21:1-29 and its significance for the South African context', Old Testament Essays $17(3), 389-403$

Grünwaldt, K., 1999, Das Heiligkeitsgesetz Leviticus 17-26. Urspüngliche Gestalt, Tradition und Theologie, De Gruyter, Berlin. (BZAW 271).

Halloway, S.W., 1992, 'Kings, Book of 1-12', in D.N. Freedman (ed.), The Anchor Bible Dictionary. Vol. 4, pp. 69-83, Doubleday, New York, NY.

Hieke, T., 2014a, Levitikus 1-15: Erster Teilband, Herder, Freiburg. (HThKAT).

Hieke, T., 2014b, Levitikus 16-27: Zweiter Teilband, Herder, Freiburg. (HThKAT).

Holter, K., 1998, 'It's not only a question of money! African Old Testament scholarship between the myths and meanings of the South and the money and methods of the North', Old Testament Essays 4(8), 240-254.

Jonker, L.C., 1997, 'Bridging the gap between Bible readers and 'professional' exegetes', Old Testament Essays 10(1), 69-83.

Jüngling, H.-W., 1999, 'Das Buch Levitikus in der Forschung zeit Karl Elligers Kommentar aus dem Jahr 1966', in H.-J. Fabry \& H.-W. Jüngling (eds.), Levitikus als Buch, pp. 1-45, Philo, Bodenheim. (BBB 119)

Klostermann, A., 1877, 'Ezechiel und das Heiligkeitsgesetz', Zeitschrift für die lutherische Theologie und Kirche 38, 401-445.

Knohl, I., 1995, The sanctuary of silence. The Priestly Torah and the Holiness School, Fortress Press, Minneapolis, MN.

Le Roux, J.H., 1993, A story of two ways: Thirty years of Old Testament scholarship in South Africa, Verba Vitae, Pretoria.

Lombaard, C., 2006, 'The relevance of Old Testament science in/for Africa: Two false pieties and focused scholarship', Old Testament Essays 19(1), 144-155.

Masenya (ngwan'a Mphahlele), M., 1997, 'Redefining ourselves: A Bosadi (womanhood) approach', Old Testament Essays 10(3), 439-448.

Masenya (ngwan'a Mphahlele), M., 1998, 'A Bosadi (womanhood) reading of Genesis 16 ', Old Testament Essays 11(2), 271-287.
Masenya (ngwan'a Mphahlele), M., 2002, ““... But you shall let every girl live”: Reading exodus 1:2-10 the Bosadi (womanhood) way', Old Testament Essays 15(1), 99112.

Masenya (ngwan'a Mphahlele), M. \& Ramantswana, H., 2012, 'Anything new under the sun of South African Old Testament scholarship? African Qoheleths' review of OTE 1994-2010', Old Testament Essays 25(3), 598-637.

Meyer, E.E., 2010, 'Dating the Priestly text in the pre-exilic period: Some remarks about anachronistic slips and other obstacles', Verbum et Ecclesia 31(1), 1-6. http://dx.doi.org/10.4102/ve.v31i1.423

Meyer, E.E., 2011, 'Respect of animal life in the book of Leviticus. How green were the Priestly authors?', Old Testament Essays 24(1), 142-158.

Meyer, E.E., 2013, 'From cult to community: The two halves of Leviticus', Verbum et Ecclesia 34(2), 6 pages.

Milgrom, J., 1991, Leviticus 1-16. A new translation with introduction and commentary, Doubleday, New York, NY. (Anchor Yale Bible).

Milgrom, J., 2000, Leviticus 17-22. A new translation with introduction and commentary, Doubleday, New York, NY. (Anchor Yale Bible).

Milgrom, J., 2001, Leviticus 23-27. A new translation with introduction and commentary, Doubleday, New York, NY. (Anchor Yale Bible).

Mosala, I.J., 1989, Biblical hermeneutics and Black Theology in South Africa, Eerdmans, Grand Rapids, MI.

Mugambi, J.N.K., 1995, From liberation to reconstruction, East African Educational Publishers, Nairobi.

Nihan, C., 2007, From Priestly Torah to Pentateuch, Mohr Siebeck, Tübingen. (FAT II/25).

Otto, E., 1999, 'Innerbiblische Exegese im Heiligkeitsgesetz Levitikus 17-26', in H.-J. Fabry \& H.-W. Jüngling (eds.), Levitikus als Buch, pp. 125-196, Philo, Bodenheim. (BBB 119).

Ramantswana, H., 2012, 'From bad to good: A dialogic reading of Genesis 1', Journa for Semitics 21(2), 237-268.

Ramantswana, H., 2013a, 'Day two of creation: Why is the rāqia' (firmament) not pronounced good?', Journal for Semitics 22(1), 101-123.

Ramantswana, H., 2013b, 'Humanity not pronounced good: A re-reading of Genesis 1:26-31 in dialogue with Genesis 2-3', Old Testament Essays 26(2), 425-444.

Ramantswana, H., 2013c, 'Humanity not pronounced good: Humanity's death within the scope of God's very good creation in light of Genesis 2-3', Old Testament Essays 26(3), 804-818.

Ramantswana, H., 2014. 'Conflicts at creation: Genesis 1-3 in dialogue with the Psalter', Old Testament Essays 27(2), 553-578.

Richards, R.R., 1994, 'National reconstruction and literary creativity in Ezra-Nehemiah A black South African perspective', Old Testament Essays 7(2), 277-301.

Rofé, A., 1988, 'The vineyard of Naboth: The origin and message of the story', Vetus Testamentum 38(1), 89-104. http://dx.doi.org/10.1163/156853388X00517

Römer, T.C., 2013, 'Deuteronomistic history', in D.C. Allison, C. Helmer, J. Schröter, T.C. Römer C.-L. Seow, B. D. Walfish, \& E. Ziolkowski (eds.), Encyclopedia of the Bible and its reception, vol. 6, pp. 648-654, De Gruyter, Berlin.

Schwartz, B.J., 2000, 'Israel's holiness: The Torah traditions', in M.J.H.M. Poorthuis \& J. Schwartz (eds.), Purity and holiness: The heritage of Leviticus, pp. 47-59, Brill, Leiden. (Jewish and Christian Perspectives 2).

Ska, J.-L., 2006, Introduction to reading the Pentateuch, Eisenbrauns, Winona Lake, IN.

Trevaskis, L.M., 2011, Holiness, ethics and ritual in Leviticus, Sheffield Phoenix Press, Sheffield. (Hebrew Bible Monographs).

Villa-Vicencio, C., 1992, A theology of reconstruction, Cambridge University Press, Cambridge. http://dx.doi.org/10.1017/CBO9780511607592

Walsh, J.T., 1992, 'Naboth', in D.N. Freedman (ed.), The Anchor Bible Dictionary, vol. 4 Doubleday, New York, NY, p. 978.

West, G., 1997, 'Finding a place among the posts for post-colonial criticism in Biblical studies in South Africa', Old Testament Essays 10(2), 322-342. http://dx.doi. org/10.1163/ej.9789004166561.i-434.22

West, G., 1998, 'Biblical scholars inventing Ancient Israel and "Ordinary Readers" of the Bible re-inventing Biblical studies', Old Testament Essays 11(3), 629-644.

West, G., 2006, 'The vocation of an African biblical scholar on the margins of biblical scholarship', Old Testament Essays 19(1), 307-336.

West, G., 2008, 'Interrogating the comparative paradigm in African scholarship', in G.O. West \& H. de Wit (eds.), African and European readers of the Bible in dialogue, pp. 37-64, Brill, Leiden.

White, M., 1994, 'Naboth's vineyard and Jehu's coup: The legitimation of dynastic extermination', Vetus Testamentum 44(1), 66-76. http://dx.doi. org/10.1163/156853394X00060 